\title{
Selenium Status of Horses in the Czech Republic
}

\author{
E. LUDVÍKOVÁ ${ }^{1}$, L. PAVLATA ${ }^{2}$, M. VYSKOČIL ${ }^{3}$, P. JAHN ${ }^{1}$ \\ ${ }^{1}$ Equine Clinic, ${ }^{2}$ Clinic of Diseases of Ruminants, ${ }^{3}$ Department of Genetics, Faculty of Veterinary Medicine, \\ University of Veterinary and Pharmaceutical Sciences Brno, Czech Republic \\ Received April 14, 2004 \\ Accepted June 6, 2005
}

\begin{abstract}
Ludvíková E., L. Pavlata, M. Vyskočil, P. Jahn: Selenium Status of Horses in the Czech Republic. Acta Vet. Brno 2005, 74: 369-375.

The aim of this study was to determine the relation between selenium concentration and activity of glutathione peroxidase (GSH-Px, EC 1.11.19) in whole blood of horses, reference ranges for the activity of GSH-Px and to evaluate the selenium status of horses in the Czech Republic. Blood samples were collected from 159 horses from 35 different farms and processed using the AAS and photometric methods to determine concentrations of selenium and the GSH-Px activity, respectively. Data on both parameters were processed using correlation and regression analysis in order to obtain reference values of GSH-Px for the indirect evaluation of the selenium status of horses. The results were also used to evaluate the occurrence of selenium deficiency in the horses examined. A highly significant linear relation was found between both variables. It can be expressed using the Spearman's coefficient of rank correlation $\left(\mathrm{r}_{\mathrm{s}}=0.873 ; p<0.01\right)$ and the regression equation $(\mathrm{y}=3.621 \mathrm{x}-28.698 ; p<0.01, \mathrm{r}=0.842)$. The value of $75 \mu \mathrm{g} \cdot \mathrm{l}^{-1}$ of selenium in whole blood is considered as a threshold of selenium deficiency in horses. According to our results, the corresponding level of the activity of GSH-Px useful in the diagnostics is $200 \mu \mathrm{kat} \cdot \mathrm{l}^{-1}$. Using these criteria, there was a high prevalence of selenium deficiency in the collection of horses examined amounting to $47 \%$ and $48 \%$ when evaluating the selenium status by the selenium concentration and the activity of GSH-Px, respectively. It can be concluded that there is a high correlation of the activity of GSH-Px and selenium concentration in whole blood of horses and that reference values of the activity of GSH-Px useful in the diagnostics of selenium deficiency in horses in the Czech Republic were determined. The occurrence of selenium deficiency in horses is a topical problem in the Czech Republic.
\end{abstract}

Glutathione peroxidase, blood, diagnostics, correlation, white muscle disease

Selenium is one of the essential nutritional elements protecting the organism from oxidative damage because it maintains low tissue levels of reactive oxygen species. Its physiological functions are due to selenoproteins, in particular. The most important of them are glutathione peroxidases (GSH-Px, EC 1.11.19), acting mainly as antioxidants. Another important selenoprotein is the iodothyronine deiodinase converting thyroxine $\left(\mathrm{T}_{4}\right)$ to the biologically active 3,3',5-triiodothyronine $\left(\mathrm{T}_{3}\right)$ or the reverse triiodothyronine $\left(\mathrm{rT}_{3}\right)$. There are other selenoproteins such as thioredoxine reductase, selenoproteins $\mathrm{P}, \mathrm{W}, \mathrm{R}, \mathrm{T}, \mathrm{N}$, selenium-binding proteins $(58,56$ and $14 \mathrm{kDa})$, selenoprotein of the spermatic capsule, proteins of the glandular epithelial prostatic cells in the rat and others (Zimmermann and Köhrle 2002; Birringer et al. 2002). Nutritional myodegeneration/white muscle disease (WMD) is the most common disease resulting from selenium deficiency in farm animals including horses. A moderate deficiency may cause low resistance to infections, infertility of mares and slow growth rate in foals (S towe 1967; Löfstedt 1997; Savage and Lew is 2002; Ishii et al. 2002). There are regions of selenium deficiency in the Czech Republic. Both ruminants (Kursa 1969; Kursa and Kroupová 1975; Pavlata et al. 2002) and humans (Kvíčala et al. 1995; 1999) in the Czech Republic were found to be deficient in selenium. The selenium status and the clinical signs of its deficiency have not been yet analysed in a detail in horses in the Czech Republic. As other animal species have been found

Address for correspondence:

MVDr. Eva Ludvíková

Equine Clinic, Faculty of Veterinary Medicine,

University of Veterinary and Pharmaceutical Sciences Brno

Palackého 1-3, 61242 Brno, Czech Republic hone: +420541562576

Fax: +420 541562395

E-mail: eludvikova@vfu.cz

http://www.vfu.cz/acta-vet/actavet.htm 
deficient in selenium and the deficiency in horses has been reported from neighbouring countries such as Poland (Gorecka et al. 1999) and Germany (Wichert et al. 2002; Vervuert et al. 2000), we can presume that the same problems are also of importance in the Czech Republic.

The selenium status in animals may be evaluated as a direct determination of its concentration in blood or as indirect derivation from measurements of the GSH-Px activity. Many authors confirmed a positive correlation between these two parameters. In the Czech Republic it was, for example, Pavlata et al. $(2000)$ in cattle $(r=0.90)$ and kids $(r=0.93)$ (Pavlata et al. 2005). Similar results concerning horses were published by Caple et al. (1978) $\mathrm{r}=0.98$, Maylin et al. (1980) $\mathrm{r}=0.94$, B lack more et al. (1982) $\mathrm{r}=0.84$, Roneus and Lindholm (1983) $\mathrm{r}=0.97$, Higushi et al. (1988) $\mathrm{r}=0.81$, Mihailovic et al. (1996) $\mathrm{r}=0.84$, confirming a highly significant linear relation between the selenium concentration and the activity of GSH-Px in whole blood. Blackmore et al. (1982), apart from the linear relation, found a quadratic one, too, with the coefficient of correlation of 0.94 . Vervuert et al. (2000) described the relation of the activity of GSH-Px in blood and the selenium concentration in serum using the linear regression. The coefficient of correlation, however, was very low $(r=0.49)$. Evaluation of the selenium status in horses using the activity of GSH-Px is considered very sensitive and useful (Caple et al. 1978; Maylin et al. 1980). Selenium is incorporated into erythrocytes during erythropoiesis only and the activity of GSH-Px is thus considered as an indicator of the long-term selenium supplementation. On the other hand, the selenium concentration in whole blood reflects the immediate status of selenium supplementation of the organism (Löfstedt 1997; Harris 1998).

There are different opinions on reference values of the selenium concentration in whole blood of horses, but the majority of authors agree on the threshold level of selenium deficiency of 55 - $75 \mu \mathrm{g} \cdot \mathrm{l}^{-1}$ (Blackmore and Brobst 1981; Blood and Radostits 1989; Strauß et al. 1993; Maas et al. 1996; Lö fstedt 1997; Valberg 2002). There is, however, disagreement over the optimum selenium concentration in blood. Blackmore and Brobst (1981), Strau $\beta$ et al. (1993) and Blood and Radostits (1989) report the range of 61 - 215 $\mu \mathrm{g} \cdot \mathrm{l}^{-1}, 140-250 \mu \mathrm{g} \cdot \mathrm{l}^{-1}$ and $140-250 \mu \mathrm{g} \cdot \mathrm{l}^{-1}$, respectively.

Reference ranges of the activity of GSH-Px are rather laboratory-specific (Maas et al. 1996). Blackmore and Brobst (1981) consider values of $83-500 \mu \mathrm{kat} \cdot \mathrm{l}^{-1}$ as a physiological range. According to Roneus and Lindholm (1983), physiological activities of GSH-Px are within the range of $300-600 \mu \mathrm{kat} \cdot \mathrm{l}^{-1}$. Blood and Radostits (1989) and Maas et al. (1996) mention the reference range of 500 - $2500 \mu \mathrm{kat} \cdot \mathrm{l}^{-1}$.

The aim of this study was to determine the relation between the selenium concentration and the activity of GSH-Px in whole blood of horses, reference ranges for the activity of GSH-Px and to evaluate the selenium status of horses in the Czech Republic using both the direct and indirect methods.

\section{Materials and Methods}

A total of 159 horses of different breeds from 35 farms in the Czech Republic were included into the study (76 Czech Warmblood horses, 26 Standardbreds, 20 Thoroughbreds, 10 Shagya Arabs, 8 Friesian horses, 6 Haflinger horses, 4 Belgian horses, 3 Shetland ponies, 2 Welsh ponies, 1 German riding pony, 1 Anglo-Arab, 1 Noric horse, 1 Hucul). Eighty one of them were mares, 25 stallions and 53 geldings with the age ranging from one month to 23 years. The use of the horses was quite variable ranging from foal rearing to racehorses, dressage, show-jumping, pleasure and breeding horses.

Blood from vena jugularis was collected from all horses. Whole blood collected into a tube with Li heparin was used to determine the selenium concentration and the activity of GSH-Px. Samples were frozen within $12 \mathrm{~h}$ of collection and kept at $-20{ }^{\circ} \mathrm{C}$ until processing. All laboratory analyses were performed at the Department of Laboratory Diagnostics of the Clinic of Diseases of Ruminants (University of Veterinary and Pharmaceutical Sciences Brno). For purposes of selenium determination the samples were mineralized in a closed system using the microwave digestion technique together with $\mathrm{HNO}_{3}$ and $\mathrm{H}_{2} \mathrm{O}_{2}$ employing the MILESTONE unit (MLS - 1200 model). The nitric acid was then evaporated and the mineral matter turned into a water solution with $20 \% \mathrm{HCl}$ 
added. Selenium was then measured in this solution using the UNICAM 939 AA spectrometer employing the hydride technique of AAS. The resulting selenium concentrations in whole blood are expressed in $\mu \mathrm{g} \cdot \mathrm{l}^{-1}$. The same sample of whole blood was used to determine the activity of GSH-Px. It was measured using the method by Paglia and Valentine (1967) employing the Ransel set supplied by the Randox company and the COBAS MIRA automatic analyser. The resulting activities of GSH-Px are expressed as $\mu \mathrm{kat} \cdot \mathrm{l}^{-1}$ of whole blood.

Data were evaluated using programs Microsoft EXCEL 97 and KyPlot computing basic statistics of the selenium concentration and the GSH-Px activity in whole blood. The statistical relation between the selenium concentration and the activity of GSH-Px in whole blood of horses was, due to the data distribution (considerable variability of values measured, differences in the mean and median), expressed using the Spearman's coefficient of rank correlation $\left(\mathrm{r}_{\mathrm{s}}\right)$ and regression equations.

\section{Results}

The basic statistics of both parameters studied are presented in Table 1. A positive correlation between both variables, best expressed by the Spearman's coefficient of rank correlation $\left(\mathrm{r}_{\mathrm{s}}=0.873 ; p<0.01\right)$, was found.

Table 1. Basic descriptive statistics of the selenium concentration and the activity of GSH-Px in whole blood of horses $(n=159)$

\begin{tabular}{|c|c|c|}
\hline & Se $\left(\mu \mathrm{gg} \cdot \mathrm{l}^{-1}\right)$ & GSH-Px $\left(\mu \mathrm{kat} \cdot \mathrm{l}^{-1}\right)$ \\
\hline Mean & 86.99 & 286.34 \\
\hline Standard deviation & 57.57 & 247.58 \\
\hline Median & 79.34 & 224.70 \\
\hline Modus & - & 241.90 \\
\hline Coefficient of variance (\%) & 66.18 & 86.46 \\
\hline Min. & 5.27 & 1.00 \\
\hline Max. & 238.10 & 952.00 \\
\hline
\end{tabular}

The linear relation of the selenium concentration and the activity of GSH-Px expressed by the equation $\mathrm{y}=3.621 \mathrm{x}-28.698$ is highly significant $(p<0.01)$ with the coefficient of correlation of $\mathrm{r}=0.842$. The relation is plotted in Fig. 1 .

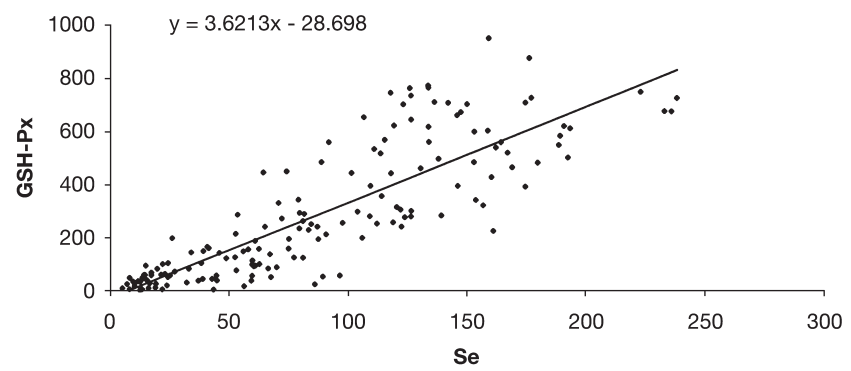

Fig. 1. Relation between the selenium concentration $\left(\mu \mathrm{g} \cdot 1^{-1}\right)$ and the activity of GSH-Px $\left(\mu \mathrm{kat} \cdot 1^{-1}\right)$ in whole blood of horses - the method of linear regression

Apart from the linear regression relation, the $2^{\text {nd }}$ degree polynomial regression between both variables was found. It was expressed by the equation $y=-0.00448 x^{2}+4.52499 x-$ 58.52877. This regression function was also highly significant $(p<0.01)$ with the index of correlation $\mathrm{I}=0.844$. This relation is shown in Fig. 2 .

Horses were divided into three groups on the base of comparison their selenium values with the published ones (Table 2).

Theoretical values of the activity of GSH-Px for the threshold selenium concentrations 


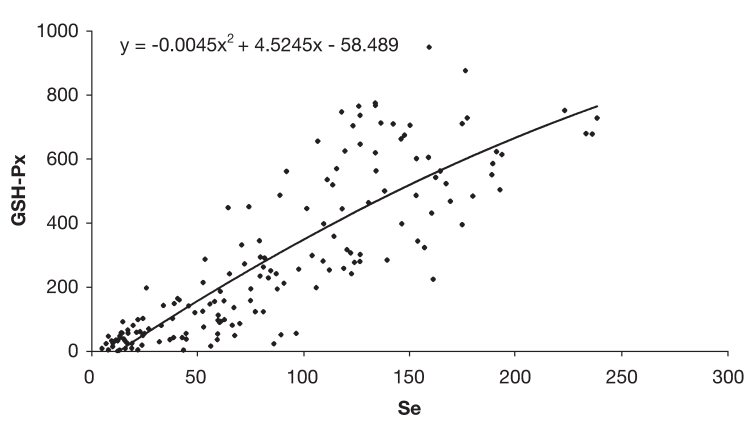

Fig. 2. Relation between the selenium concentration $\left(\mu \mathrm{g} \cdot 1^{-1}\right)$ and the activity of GSH-Px $\left(\mu \mathrm{kat} \cdot 1^{-1}\right)$ in whole blood of horses - the method of the $2^{\text {nd }}$ degree polynomial regression

Table 2. Evaluation of the selenium status in horses using the selenium concentration in whole blood $(\mathrm{n}=159)$

\begin{tabular}{|c|c|c|c|c|}
\hline $\begin{array}{c}\mathrm{Se} \\
\left(\mu \mathrm{g} \cdot \mathrm{l}^{-1}\right)\end{array}$ & $\mathrm{n}$ & $\%$ & Cumulative \% & Se status \\
\hline$<50$ & 50 & 31 & 47 & Deficient \\
\hline $50-75$ & 26 & 16 & & Marginal \\
\hline$>75$ & 83 & 53 & 53 & Adequate \\
\hline
\end{tabular}

$\left(50 \mu \mathrm{g} \cdot \mathrm{l}^{-1}\right.$ and $75 \mu \mathrm{g} \cdot \mathrm{l}^{-1}$ ) were calculated using this linear equation (i.e., $152 \mu \mathrm{kat} \cdot \mathrm{l}^{-1}$ and 243 $\mu \mathrm{kat} \cdot \mathrm{l}^{-1}$ ). The linear variable relation plot in Fig. 1 documents that most values of the activity of GSH-Px were lower than $200 \mu \mathrm{kat} \cdot \mathrm{l}^{-1}$ up to the selenium concentration of $75 \mu \mathrm{g} \cdot \mathrm{l}^{-1}$. On the base of these results the ranges given in Table 3 were used for purposes of deriving the activity of GSH-Px in the diagnostics of selenium deficiency.

Table 3. Evaluation of the selenium status in horses using the activity of GSH-Px in whole blood ( $n=159)$

\begin{tabular}{|c|c|c|c|c|}
\hline $\begin{array}{c}\text { GSH-Px } \\
\left(\mu \mathrm{kat}^{-{ }^{-1}}\right)\end{array}$ & $\mathrm{n}$ & $\%$ & Cumulative $\%$ & Se status \\
\hline$<100$ & 55 & 34 & 48 & Deficient \\
\hline $100-200$ & 22 & 14 & & Marginal \\
\hline$>200$ & 82 & 52 & 52 & Adequate \\
\hline
\end{tabular}

From data in Table 2 it is evident that $47 \%$ of 159 horses examined are low in selenium. Evaluating the selenium status using the activity of GSH-Px (Table 3) $48 \%$ of horses were selenium deficient. The difference in results obtained using both methods of the selenium status evaluation is $1 \%$. Using both the methods together ( $\mathrm{Se}<75 \mu \mathrm{g} \cdot \mathrm{l}^{-1}$ and GSH-Px $<$ $200 \mu \mathrm{kat} \cdot \mathrm{l}^{-1}$ ) low levels were found in 70 horses $(44 \%)$. The difference in the percentage of selenium deficient horses is thus by $4 \%$ and $3 \%$ lower than evaluating the status only using the activity of GSH-Px and the concentration of selenium in whole blood, respectively.

Table 4 presents results of mean values of selenium concentrations and the activity of GSH-Px in whole blood of horses from individual farms where at least three horses were examined. Relatively low values of the coefficient of variance in most herds are characteristic for low variability of the selenium concentration and the activity of GSH-Px in whole blood due to the balanced selenium status in horses. 
Table 4. Mean values of selenium concentrations and the activity of GSH-Px in whole blood of horses from individual farms of at least three horses examined (standard deviation (S.D.), coefficient of variance (v) and the use of horses ( $\mathrm{R}$ - racing, $\mathrm{S}$ - show jumping, endurance and dressage, $\mathrm{H}$ - hobby riding, $\mathrm{B}$ - breeding)

\begin{tabular}{|c|c|c|c|c|c|c|c|c|}
\hline $\begin{array}{c}\text { Herd } \\
\text { No. }\end{array}$ & Use & $\mathrm{n}$ & $\begin{array}{c}\mathrm{Se} \\
\left(\mu \mathrm{g} \cdot \mathrm{l}^{-1}\right)\end{array}$ & S.D. & $\begin{array}{c}\mathrm{v} \\
(\%)\end{array}$ & $\begin{array}{c}\text { GSH-Px } \\
\left(\mu \mathrm{kat} \cdot \mathrm{l}^{-1}\right)\end{array}$ & S.D. & $\begin{array}{c}\mathrm{v} \\
(\%)\end{array}$ \\
\hline 1 & $\mathrm{R}$ & 15 & 161.11 & 34.45 & 21.38 & 599.19 & 129.85 & 21.67 \\
\hline 2 & $\mathrm{H}$ & 12 & 69.54 & 30.33 & 43.61 & 187.51 & 42.42 & 22.62 \\
\hline 3 & $\mathrm{H}$ & 4 & 173.00 & 13.04 & 7.53 & 550.95 & 110.32 & 20.02 \\
\hline 4 & $\mathrm{H}$ & 12 & 109.33 & 23.33 & 21.33 & 281.71 & 67.67 & 24.04 \\
\hline 5 & $\mathrm{~B}$ & 12 & 32.95 & 19.90 & 60.39 & 120.75 & 128.40 & 106.33 \\
\hline 6 & $\mathrm{~B}$ & 11 & 174.24 & 26.22 & 15.04 & 287.66 & 99.72 & 34.66 \\
\hline 7 & $\mathrm{H}$ & 6 & 26.97 & 15.88 & 58.88 & 69.10 & 22.89 & 33.12 \\
\hline 8 & $\mathrm{R}$ & 6 & 193.82 & 42.13 & 21.73 & 710.32 & 105.21 & 14.81 \\
\hline 9 & $\mathrm{R}$ & 8 & 109.36 & 20.26 & 18.52 & 513.90 & 104.62 & 20.35 \\
\hline 10 & $\mathrm{H}$ & 12 & 50.53 & 31.55 & 62.24 & 103.36 & 119.71 & 115.80 \\
\hline 11 & $\mathrm{H}$ & 6 & 28.55 & 11.95 & 41.85 & 54.27 & 21.60 & 39.80 \\
\hline 12 & $\mathrm{H}$ & 6 & 53.61 & 21.11 & 39.37 & 72.22 & 31.84 & 44.08 \\
\hline 13 & $\mathrm{H}$ & 4 & 76.58 & 15.56 & 20.31 & 36.60 & 16.81 & 45.92 \\
\hline 14 & $\mathrm{H}$ & 6 & 67.78 & 19.38 & 28.59 & 114.62 & 50.30 & 43.88 \\
\hline 15 & $\mathrm{H}$ & 6 & 12.61 & 3.13 & 24.82 & 34.18 & 14.29 & 41.80 \\
\hline 16 & $\mathrm{~B}$ & 7 & 17.81 & 7.31 & 41.04 & 72.87 & 34.51 & 47.35 \\
\hline 17 & $\mathrm{~B}$ & 3 & 74.55 & 15.29 & 20.51 & 166.20 & 65.42 & 39.36 \\
\hline 18 & $\mathrm{R}$ S & 5 & 88.82 & 35.51 & 39.98 & 490.76 & 229.96 & 46.86 \\
\hline
\end{tabular}

\section{Discussion}

Our results of a highly significant linear relation between the selenium concentration and the activity of GSH-Px in whole blood correspond to results of other authors (Caple et al. 1978; Maylin et al. 1980; Blackmore et al. 1982; Roneus and Lindholm 1983; Higushi et al. 1988; Mihailovic et al. 1996). Apart from this linear relation, we found also a highly significant relation of the $2^{\text {nd }}$ degree polynomial expressing the relation between the selenium concentration and the activity of GSH-Px a bit better. This finding corresponds to the results of Blackmore et al. (1982).

Regarding the value of the correlation coefficient, it is not possible to assign an exact value of the selenium concentration in whole blood to each measured activity of GSH-Px. It is, however, possible to divide the examined animals into categories of deficient, marginal and adequately selenium-saturated horses with this division being sufficient enough from the practical point of view. Published reference ranges of the activity of GSHPx are quite variable. According to Maas et al. (1996) and Pavlata et al. (2000) the reference range is laboratory-specific. In addition to that, the activity of GSH-Px responds to selenium supplementation only after 5 - 6 weeks (Maylin et al. 1980). According to Stow (1967) increased activities of GSH-Px can be expected as late as 45 - 60 days after selenium administration, i.e., after the time needed for the exchange of erythrocytes in blood (Roneus and Lindholm 1983). That is why it may happen that the current selenium concentration is adequate, but the activity of GSH-Px is low. On the other hand, end of selenium supplementation may result in measurements of adequate activities of GSH-Px, even when the selenium concentration in blood has already dropped below the optimum. The activity of GSH-Px may thus be used as an indicator of the long-term selenium status (Löfstedt 1997; Harris 1998). It may, therefore, be recommended to determine both the selenium concentration and the activity of GSH-Px in order to characterise the selenium status exactly. 
A total of $47 \%$ of horses were low in selenium according to the results of our measurements. Using the activity of GSH-Px to evaluate the selenium status, $48 \%$ were selenium deficient. There was even a difference of $3 \%$ when evaluating the selenium status by measurements of both the activity of GSH-Px and the selenium concentration in whole blood and the selenium concentration alone. These differences, however, are clinically unimportant. The differences demonstrate that, when evaluating the selenium status on the base of the activity of GSH-Px only, level of the selenium status can be overestimated. Our results document a relatively high prevalence of selenium deficiency in horses in the Czech Republic. Differences among individual farms depend largely on the nutrition. It is clear that the standard feeding ration (hay and grains) is not adequate regarding the selenium content in the Czech Republic. Considering the use of horses, there were differences in the selenium status of racing, show jumping, endurance, dressage, hobby riding, and breeding horses. While racing horses had adequate levels of selenium, hobby horses were mostly deficient. Results of breeding horses from individual farms were variable (Table 4). The poor selenium status of breeding mares is an important predisposing factor of nutritional myodegeneration in foals.

It can be concluded from our results that selenium deficiency in horses may be diagnosed using both the direct and indirect methods. The value of $200 \mu \mathrm{kat}^{-1} \mathrm{may}^{-1}$ be considered a threshold level of the activity of GSH-Px useful in determining selenium deficiency in horses. Our findings document a high prevalence of selenium deficiency in horses in the Czech Republic, the need for its exact diagnostics and supplementation of this element.

\section{Hodnocení stavu zásobení koní v České republice selenem}

Cílem práce bylo stanovit těsnost vztahu mezi koncentrací selenu a aktivitou glutathionperoxidázy (GSH-Px) v plné krvi koní, určit referenční rozmezí hodnot aktivity GSH-Px pro hodnocení stavu zásobení koní selenem v podmínkách České republiky a vyhodnotit stav zásobení vyšetřených koní selenem. V rámci studie byla odebrána krev od 159 koní pocházejících z 35 různých chovů a provedeno stanovení koncentrace selenu metodou AAS a aktivity GSH-Px fotometrickou metodou. Mezi výsledky obou vyšetřovaných parametrů byla provedena korelační a regresní analýza a na základě jejich výsledků stanoveny referenční hodnoty GSH-Px pro nepřímé hodnocení stavu zásobení koní selenem a provedeno vyhodnocení výskytu deficitu selenu u vyšetřených koní. Mezi oběma proměnnými byl zjištěn statisticky vysoce významný lineární vztah vyjádřený Spearmanovým koeficientem pořadové korelace $\left(\mathrm{r}_{\mathrm{s}}=0,873 ; p<0,01\right)$ a rovnicí regresní přímky dokládající lineární závislost $(\mathrm{y}=$ $3,621 \mathrm{x}-28,698 ; p<0,01, \mathrm{r}=0,842)$. S využitím literaturou doporučované hodnoty selenu v plné krvi koní $75 \mu \mathrm{g} \cdot \mathrm{l}^{-1}$, jakožto hranice deficitu selenu, byla pro praktické použití v diagnostice karence selenu stanovena této hodnotě odpovídající aktivita GSHPx $200 \mu \mathrm{kat} \cdot \mathrm{l}^{-1}$. Při použití těchto kritérií byl u vyšetřených koní zjištěn vysoký výskyt karence selenu (u 47 \% vyšetřených koní při vyhodnocení dle koncentrace selenu a u 48 \% při vyhodnocení podle aktivity GSH-Px). Na základě zjištěných výsledků lze konstatovat, že byla potvrzena vysoká závislost mezi aktivitou GSH-Px a koncentrací selenu v plné krvi koní, byly stanoveny př́islušné hodnoty aktivity GSH-Px pro účely diagnostiky karence selenu u koní v České republice. Výskyt deficitu tohoto prvku je v našich chovech koní velmi aktuálním problémem.

\section{Acknowledgement}

The work was supported by the Ministry of Education, Youth and Sports of the Czech Republic (Grant No.161700002 and partly MSM6215712403). 


\section{References}

BIRRINGER M, PILAWA S, FLOHÉ L 2002: Trends in selenium biochemistry. Nat Prod Rep 19: 693-718 BLACKMORE DJ, BROBST D 1981: Biochemical values in equine medicine. The Animal Health Trust, 108 p.

BLACKMORE DJ, CAMPBELL C, DANT C, HOLDEN JE, KENT JE 1982: Selenium status of thoroughbreds in the United Kingdom. Equine Vet J 14: 139-143

BLOOD DC, RADOSTITS OM 1989: Veterinary medicine. A textbook of the disease of cattle, sheep, pigs and horses. Seventh edition. English Language Book Society/Baillière Tindall, $1502 \mathrm{p}$.

CAPLE IW, EDWARDS SJA, FORSYTH WM, WHITELEY P, SELTH RH, FULTON LJ 1978: Blood glutathione peroxidase activity in horses in relation to muscular dystrophy and selenium nutrition. Aust Vet J 54: $57-60$

GORECKA R, SIKORA J, SITARSKA E, OSINKA B, DZIEKAN P 1999: Acute enzootic muscular dystrophy in foal and prophylactic administration selenium with vitamin $\mathrm{E}$ in mares. Med Wet 55: 535-538

HIGUCHI T, ICHIJO S, OSAME S, OHISHI H 1988: Studies on serum selenium and tocopherol in white muscle disease of foal. Jpn J Vet Sci 51: 52-59

HARRIS AP 1998: Musculoskeletal Disease. In: REED SM, BAYLY WM (Ed).: Equine internal medicine. W. B. Saunders Company, St. Louis, pp. 371-426.

ISHII M, OGATA H, SHIMIZU H, TAKEUCHI Y, NOZOWA T, YAMAMOTO Y, OKAMOTO T, SHIMAMURA T, UTSUMI A, JITSUKAWA J, ENDO M, FUKUDA T, YAMANOI T 2002: Effects of vitamin $\mathrm{E}$ and selenium administration on pregnant, heavy draft mares on placental retention time and reproductive performance and on white muscle disease in their foals. J Equine Vet Sci 22: 213-220

KURSA J 1969: Nutriční svalová degenerace u mladého skotu v distriktu Šumavy. Vet Med (Praha) 20: $549-559$

KURSA J, KLEIN Z, LAVIČKA M 1970: Generalizovaná forma svalové degenerace u hř́iběte. Veterinářství 20: 540-541

KURSA J, KROUPOVÁ V 1975: Selenium content in cattle hair in areas with incidence of nutrition-induced muscular dystrophy (in Czech). Vet Med (Praha) 20: 75-81

KVÍČALA J, ZAMRAZIL V, ČEŘOVSKÁ J, BEDNÁŘ J, JANDA J 1995: Evaluation of selenium supply and status of inhabitants in 3 selected rural and urban regions of the Czech-Republic. Biol Tr Elem Res 47: $365-375$

KVÍČALA J, ZAMRAZIL V, JIRÁNEK V 1999: Characterization of selenium status of inhabitants in the region Ústí nad Orlicí, Czech Republic by INAA of blood serum and hair and fluorometric analysis of urine. Biol Tr Elem Res 71-2: 31-39

LÖFSTEDT J 1997: White muscle disease of foals. Veterinary clinics of North America. Equine Pract 13: $169-185$

MAAS J, PARISH SM, HODGSON DR, VALBERG SJ 1996: Nutritional myodegeneration. In: SMITH BP et al. (Ed).: Large animal internal medicine, Mosby, St. Louis, pp. 1513-1518.

MAYLIN GA, RUBIN DS, LEIN DH 1980: Selenium and vitamin E in horses. Cornell Vet 70: 272-289

MIHAILOVIC M, ILIC V, LINDBERG P 1996: Blood glutathione peroxidase activity, selenium and vitamin E concentrations of race horses in Serbia. Acta Vet Beograd 46: 27-32

PAGLIA DE, VALENTINE WN 1967: Studies on the quantitative and qualitative characterisation of erythrocyte gluthatione peroxidase. J Lab Clin Med 70: 158-169

PAVLATA L, ILLEK J, PECHOVÁ A, MATĚJÍČEK M 2002: Selenium status in cattle in the Czech Republic. Acta Vet Brno 71: 3-8

PAVLATA L, PECHOVÁ A, ILLEK J 2000: Direct and indirect assessment of status in cattle - a comparison. Acta Vet Brno 69: 281-287

PAVLATA L, ŠLOSÁRKOVÁ S, FLEISCHER P, PECHOVÁ A 2005: Effects of increased iodine supply on the selenium status of kids. Vet Med-Czech 50: 186-194

RONEUS BO, LINDHOLM A 1983: Glutathione peroxidase activity in the blood of healthy horses given different selenium supplementation. Nord Vet Med 35: 337-345

SAVAGE CJ, LEWIS LD 2002: Selenium. In: STASHAK TS (Ed): Adams lameness in horses, Lippincott Williams \& Wilkins, Philadephia, pp. 380-382.

STOWE HD 1967: Serum selenium and related parameters of naturally and experimentally fed horses. J Nutr 93: 60-64

STRAUß V, ZEIDNER S, NOACK S 1993: Richtwerte wichtiger Laborparameter bei Haustieren. Paul Kieser GmbH Drucerei und Verlag, Ingolstadt, $131 \mathrm{p}$.

VALBERG SJ 2002: A review of the diagnosis and treatment of rhabdomyolysis in foals. AAEP Proceedings 48: $117-121$

VERVUERT I, COENEN M, HOLTERSHINKEN M, VENNER M, RUST P 2000: Assessment of selenium status in horses - new aspects. Tierarztl Prax G N 28: 172-177

WICHERT B, FRANK T, KIENZLE E 2002: Supply with trace elements zinc, copper and selenium in horses in south Bavaria. Tierarztl Prax G N 30: 107-113

ZIMMERMANN MB, KÖHRLE J 2002: The impact of iron and selenium deficiencies on iodine and thyroid metabolism: biochemistry and relevance to public health. Thyroid 12: 867-878 